\title{
BLUE HONEYSUCKLE BERRY (LONICERA CAERULEA L.), AS RAW MATERIAL, IS PARTICULARLY PREDISPOSED TO THE PRODUCTION OF FUNCTIONAL FOODS
}

\author{
Anna Grobelna ${ }^{1 凶}$, Stanisław Kalisz ${ }^{1}$, Marek Kieliszek ${ }^{2}$, Liviu Giurgiulescu ${ }^{3}$ \\ ${ }^{1}$ Institute of Food Sciences, Department of Food Technology and Assessment, \\ Warsaw University of Life Sciences - SGGW, 159C Nowoursynowska St., 02-776 Warsaw, Poland; \\ ${ }^{2}$ Institute of Food Sciences, Department of Food Biotechnology and Microbiology, \\ Warsaw University of Life Sciences - SGGW, 159C Nowoursynowska St., 02-776 Warsaw, Poland; \\ ${ }^{3}$ Chemistry-Biology Department, Technical University of Cluj Napoca, \\ North Universitary Center of Baia Mare, 76 Victoriei St., Romania

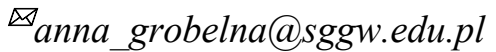

https://doi.org/10.34302/crpjfst/2020.12.3.12

Article history:

Received:

Accepted:

10 September 2019

18 June 2020

Keywords:

Blue honeysuckle;

Lonicera caerulea $L$.

Anthocyanins;

Polyphenols;

Food.

\section{ABSTRACT}

The aim of this work was to present the characteristics of the blue honeysuckle berry and its practical application in the food industry. Blue honeysuckle berries are a source of valuable and essential nutrients. They are becoming more and more popular also because of their valuable medicinal properties. Blue honeysuckle berry, due to the presence of compounds with strong antioxidant and anti-inflammatory properties, reduces the harmful effects of free radicals. It is a rich source of vitamin $\mathrm{C}$, contains polyphenols, and is popularly used as an ingredient of dietary supplements and medicinal preparations. Due to its high nutritional value, its cultivation is of utmost importance. Its inherent strength at low temperatures and early maturation render it valuable as a raw material. The growing interest of producers in new products rich in health-promoting properties makes them more attractive to the potential consumer. In addition, consumers are constantly seeking better alternatives, healthier products of plant origin, in a bid to rule out the negative aspects, and this will be an alternative to the widely existing food products.

\section{Introduction}

Blue honeysuckle (Lonicera caerulea L.) is a plant belonging to the Caprifoliaceae family. Other names of this plant include, but are not limited to, "haskap," "sweet berry honeysuckle," "kamchatka honeysuckle," "edible honeysuckle," and "honeyberry" (Jurgoński et al., 2013; Jurikova, et al., 2012a; Becker and Szakiel, 2019; Rupasinghe et al., 2018). In Japan and Canada, it is most commonly known as "haskap," and in areas of Siberia and Russia it is known as "zhimolost"
(Becker and Szakiel, 2019; Celli et al., 2014). Currently, this plant is cultivated in Japan, Russia, Canada, Poland, Czech Republic, Slovakia, Austria, and other countries (Oszmiański and Kucharska, 2018; Auzanneau et al., 2018).

It is a long-lived, fruit-bearing shrub that originated from distant Siberia and northeastern Asia. Its natural habitat includes wet areas along rivers and bogs as well as high mountains (Celli et al., 2014). The first mention of this plant dates back to the 17 th century, and the first attempts at 
domestication took place in Russia at the beginning of the 20th century. Around 1950, work in Russia intensified to develop cultivars with the highest possible yield, larger and sweeter fruits, and mechanical harvesting characteristics (i.e. balanced ripening of fruits). Similar work began only at the end of the 20th century in Canada and in several European countries (i.e. Poland, Czech Republic, Lithuania, Finland, and Slovakia) (Celli et al., 2014; EFSA, 2018; Becker and Szakiel, 2019).

Currently, the widely grown Canadian varieties are obtained from the cross-pollination of L. caerulea var. kamtschatica with the Canadian variety Lonicera kamtschatica var. villosa and the Japanese (Hokkaido) variety $L$. caerulea var. emphyllocalyx (Thompson and Barney, 2007). In turn, Polish varieties are derived from the cross-pollination of $L$. caerulea var. kamtschatica with $L$. caerulea var. edulis (Becker and Szakiel, 2019). Only the above mentioned species result in tasty, aromatic, sweet-sour fruits of the highbush blueberry or bilberry type. On the other hand, fruits from shrubs of varieties with Lonicera altaica and Lonicera pallasii in their pedigree are characterized by a marked tartness and bitterness resulting mainly from the high content of iridoid glycosides and esters of malic and citric acid (Jurikova, et al., 2012a; Celli et al., 2014).

The varieties in Poland include "Wojtek," "Jolanta," "Atut," "Duet," "Brazowa," "Czarna," and "Warszawa" (Becker and Szakiel, 2019; Kaczmarska et al., 2015; Ochmian et al., 2012; Ochmian et al., 2008); while the most popular Canadian varieties are "Blue Belle," "Blue Bird," "Blue Moon," "Blue Velvet," "Tundra," "Aurora," "Borealis," "Indigo Gem," and "Honeybee" (Becker and Szakiel, 2019; Rupasinghe et al., 2018; Rupasinghe et al., 2012).

The fully mature shrub is dense and upright (Figure 1).

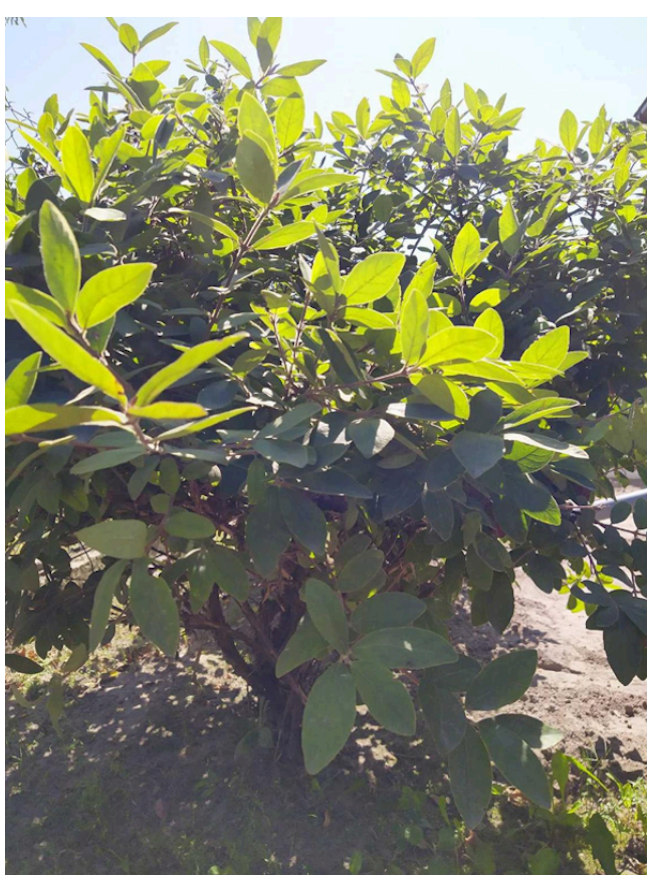

Figure 1. Blue honeysuckle bush.

The shrubs can reach a height of $2 \mathrm{~m}$ and a width of 1.5-2 m. The flowers are pale yellow, melliferous, and have a delicate, pleasant aroma (Figure 2).

The bush blooms with the development of leaves. In Canada (Saskatoon), Blue Honeysuckle begins to flower at the beginning of May, while in Poland it usually blooms at the end of April (Gawroński et al., 2014). However, the time of flowering is highly influenced by climatic conditions and, above all, temperature. It has been proven that there can be large differences in flowering time (even more than 2 weeks) of the same varieties in different years. The other important factor is the varietydepending on the variety, flowering time can last from 7 to 15 days (Dawson, 2017). As this is not a self-pollinating plant, it requires a different variety-which flowers at the same time-to be present close by, for cross-pollination will occur. A solitary blue honeysuckle shrub can also bear fruit, but less abundantly (Frier et al., 2016). 


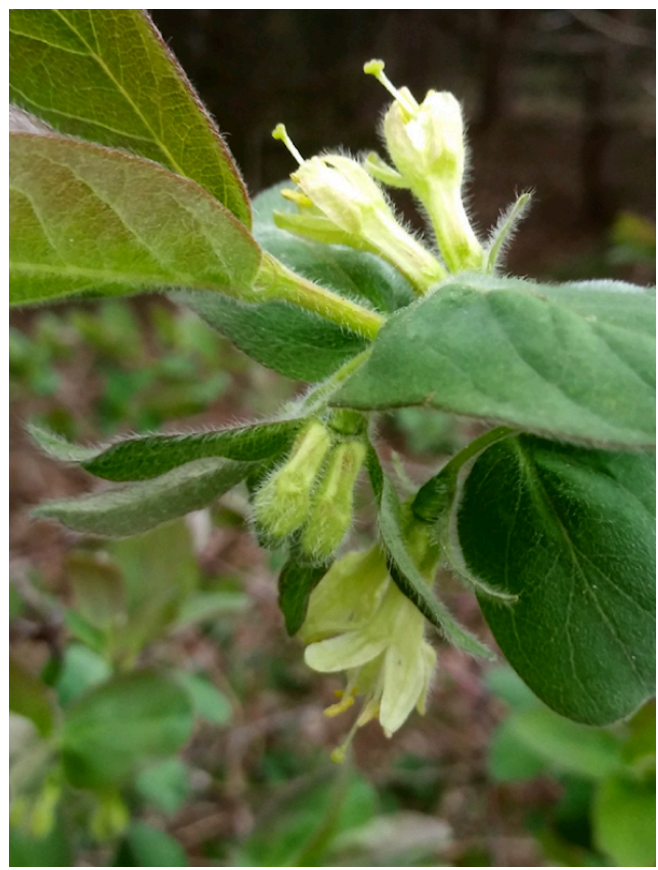

Figure 2. Blue honeysuckle flowers.

Blue honeysuckle starts bearing fruit in the second year after planting, and the full yield (3$5 \mathrm{~kg}$ ) can be harvested $8-15$ years after planting (Dawson, 2017). The berries are fleshy, elongated, navy blue in color, and covered with a waxy, blue coating (Figure 3 ).

In addition, the fruit contains about 20 small seeds, which are undetectable during eating. The weight of the fruit varies from 0.3 to $3.8 \mathrm{~g}$ while the length varies from 2 to $3 \mathrm{~cm}$, depending on the variety and climatic conditions. The flavor of the berries is sweet and sour, slightly tart or bitter (Becker and Szakiel, 2019; Celli et al., 2014; Jurikova et al., 2012a; Ochmian et al., 2008). Blue honeysuckle is long-lived and can bear fruit for up to 30 years. Shrubs that are 20to 25-year-old can die out or yield less, but treatments such as pruning and removing older stems and branches can help the plant to grow afresh (Becker and Szakiel, 2019; Dawson, 2017). This is a plant that tolerates shaded areas, but for maximum yield, it is recommended to have full sun exposure. The soil requirements are relatively minimal and acidification is not necessary unlike high blueberries. It tolerates a wide range of soil $\mathrm{pH}$ and the most favorable $\mathrm{pH}$ range is 5.5-8.0. Blue honeysuckle can grow on sandy and clay soils as well as peaty and slightly acidic soils (Dawson, 2017). It is very rarely pest-attacked and therefore does not require special protection against fungal diseases and other pathogens (Celli et al., 2014). Blue honeysuckle demonstrates very high frost resistance-shrubs can withstand temperatures down to $-40^{\circ} \mathrm{C}$ and flowers down to $-8^{\circ} \mathrm{C}$ (Ochmian et al., 2008). As a result, the climate in Central Europe, Northern Europe, Canada, and USA is favorable for blue honeysuckle (Becker and Szakiel, 2019).

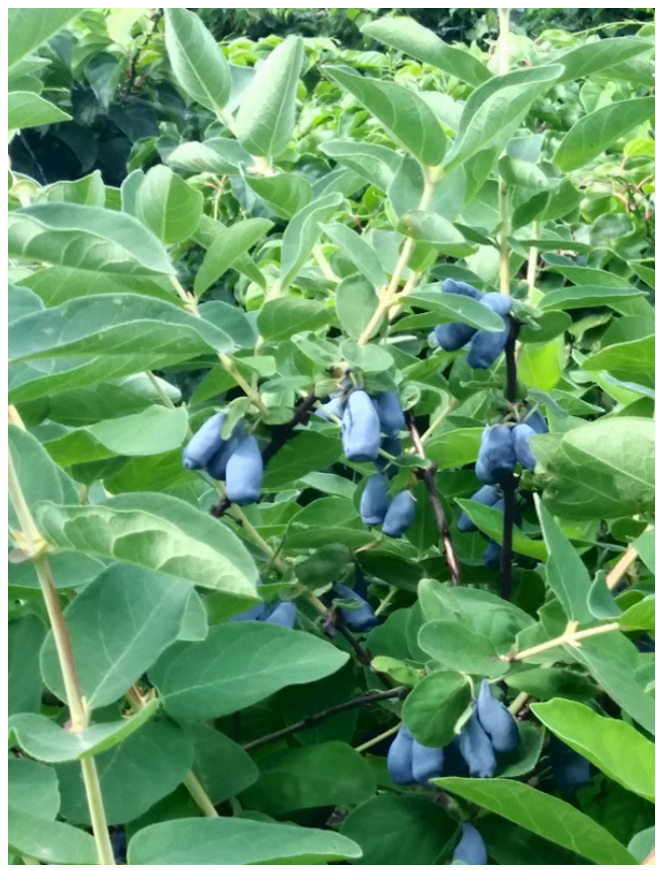

Figure 3. Blue honeysuckle fruits.

2. The content of bioactive compounds and pro-health properties of blue honeysuckle berries

Blue honeysuckle berries are a valuable source of vitamins, minerals, and secondary metabolites with bioactive properties that are important for maintaining proper human health. Properties of L. caerulea L. have been appreciated for centuries by the folk medicine of China, Japan, and northern Russia (Kaczmarska 
et al., 2015). This plant was even called the "elixir of life" by the indigenous Ainu family living on the island of Hokkaido (Celli et al., 2014). The raw material was used to treat fever, headaches, and urinary tract diseases (Kaczmarska et al., 2015), and the fruits were used in coronary heart disease, respiratory infections, and liver and gallbladder disorders. An infusion of leaves and flowers of this plant was used as a medicine against bacterial and viral infections of the oral cavity and throat, in cold and flu and as a diuretic. Additionally, the fruits were used to treat gastrointestinal disorders and eye diseases (Ochmian et al., 2012; Caprioli et al., 2016; Becker and Szakiel, 2019). Contemporary scientific research has confirmed the therapeutic properties of blue honeysuckle, which result from the healthpromoting chemical composition of this plant. It was found that extracts from blue honeysuckle berries are effective both in chemoprevention and in chemotherapy. Their anticancer property is related to the induction of antioxidant defense enzymes, inhibition of cancer cell proliferation, and factors causing metastases (Rupasinghe et al., 2018). Its cardiovascular benefit has also been proven. A recent study on the oral intake of blue honeysuckle extracts by elderly people showed a significant decrease in diastolic blood pressure and relative heart rate (Bell \& Williams, 2018). It was also found that consumption of these berries inhibited postprandial serum triacylglycerol and glucose levels in rats (Takahashi et al., 2014) and decreased plasma high-density lipoprotein cholesterol levels (Jurgoński et al., 2013). Blue honeysuckle berries also have strong antidiabetic properties. In one study, blue honeysuckle berries showed the strongest $\alpha$ glucosidase inhibitory activity among fruits such as highbush blueberry, bilberry, blackcurrant, sweet cherry, and red gooseberry (Podsędek et al., 2014). Inhibition of $\alpha$ glucosidase and $\beta$-fructosidase allows delaying disaccharide digestion, which is important for postprandial hyperglycemia control in patients with diabetes (Johnson et al., 2011). In addition, in several studies antibacterial properties of blue honeysuckle berries were observed. Palíková et al. showed that freeze-dried berries and its extracts rich in polyphenolic compounds decreased artificial adhesion and biofilm formation of pathogenic microorganism strains, i.e. Candida parapsilosis, Staphylococcus epidermidis, Enterococcus faecalis, and Streptococcus mutans. Adhesion to tissues and biofilm formation are the culminant stages of microbial colonization, and then infection (Palíková et al., 2008; Rupasinghe et al., 2018). Another important observation showed that blue honeysuckle berries effectively inhibited the development of bacteria often transmitted through food such as Escherichia coli, Campylobacter jejuni, and Listeria monocytogenes, but did not inhibit the growth of bacteria such as Bifidobacterium bifidum (Raudsepp et al., 2013). Moreover, polyphenols present in blue honeysuckle berries improved the functioning of the intestinal microflora (Taira et al., 2015). The beneficial effect of blue honeysuckle berries on thyroid diseases is also shown. A mouse with hyperthyroidism, which was given an oral extract of blue honeysuckle berries, was shown to have decreased thyroid hormones secretion in a study (Rupasinghe et al., 2018).

It should be noted that the chemical composition of blue honeysuckle may differ depending on the genetic characteristics of the different varieties, the climatic conditions, the geographical location of the crop, the agrotechnical treatments used (irrigation and fertilization), and the harvest period (Kaczmarska et al., 2015). Fully ripened fruits contain between $12.4 \%$ and $20.3 \%$ of dry matter, with a predominance of fructose and glucose (Dawson, 2017; Rupasinghe et al., 2018). In some cultivars grown in Poland, the presence of sorbitol was also detected, while sucrose was found in cultivars originating from Canada (Wojdyło et al., 2013; Rupasinghe et al., 2015; Senica et al., 2018). In general, compared to 
other popular berries, blue honeysuckle berries contain much lower sugar content (Senica et al., 2018). They are characterized by a high content of organic acids, among which citric acid is the most dominant. Wojdyło et al. found that citric acid constituted $47 \%$ of all organic acids, among which malic, phytic, oxalic, quinic, and shikimic acids were also present. At the same time, oxalic, quinic, and shikimic acids were present in the lowest amounts and constituted, respectively, $5 \%, 4 \%$, and $1 \%$ (Wojdyło et al., 2013). Blue honeysuckle berries are characterized by a high content of vitamin $\mathrm{C}$, which is comparable to or higher than the content in fruits considered to be the best sources of this vitamin (oranges, strawberries, raspberries, blackberries) (Rupasinghe et al., 2018). The vitamin $C$ content can reach up to $187 \mathrm{mg} / 100 \mathrm{~g}$ fresh weight (FW) (Jurikova et al., $2012 \mathrm{~b}$ ). Among the mineral components, potassium is dominant, followed by phosphorus and calcium, magnesium and iron in smaller amounts, and trace amounts of manganese, copper, and zinc (Dawson, 2017; Rupasinghe et al., 2018). Blue honeysuckle berries are also a good source of pectin, comparable to raspberries (Wojdyło et al., 2013). Fiber may constitute on average $8.3 \%$ (Caprioli et al., 2016), carbohydrates from $10.2 \%$ to $15.6 \%$ (Rupasinghe et al., 2012), and proteins from $2.1 \%$ to $8.4 \%$ (Rupasinghe et al., 2018). Fat content may vary between $0.01 \%$ and $4.8 \%$ depending on the location and variety (Rupasinghe et al., 2012).

Blue honeysuckle is considered particularly important for its high content of antioxidant compounds from the polyphenol group, which have the ability to neutralize free radical activity (Jurikova et al., 2012b). Polyphenols are a very large group of compounds with different structure and physical, chemical, and biological properties. Depending on the position of the phenolic ring and the degree of oxidation of the pyranone ring, the following are distinguished: phenolic acids, flavones, flavanones, flavonols, flavan-3-ols, anthocyanins, and chalcones
(Jurikova et al., 2012a; Wojdyło et al., 2013; Panche et al., 2016).

Blue honeysuckle berries are known for their remarkably high content of anthocyanins (from 400 to $1500 \mathrm{mg} / 100 \mathrm{~g}$ ) (Jurikova et al., 2012a). Anthocyanins are the compounds responsible for the dark blue color of these fruits. The most abundant anthocyanin is cyanidin-3-glucoside $\quad(79 \%-92 \%)$, whereas cyanidin-3,5-diglucoside, peonidin-3-glucoside, cyanidin-3-rutinoside, peonidin-3-rutinoside, and pelargonidin-3-glucoside occur in smaller amounts (Wang et al., 2015; Rupasinghe et al., 2018). Furthermore, Wang et al. also reported the presence of cyanidin-3-acetylhexoside and peonidin-3-acetylhexoside in cultivars grown in China (Wang et al., 2015). Research has also shown that a higher amount of anthocyanins is contained in the skin than in the flesh of these fruits. The total content of anthocyanins in blue honeysuckle berries is comparable to the content in chokeberries and elderberries - which are two of the richest sources of these ingredients (Becker and Szakiel, 2019). Numerous studies have confirmed a wide range of pro-health and therapeutic properties of anthocyanins, i.e. antioxidant, anticancer, antidiabetic, and antibacterial properties, besides improving the functioning of the visual system (Khoo et al., 2017).

The next group of polyphenolic compounds present in blue honeysuckle berries is phenolic acids. In terms of chemical structure, phenolic acids are divided into hydroxybenzoic acids with carbon skeleton $\mathrm{C}_{6}-\mathrm{C}_{1}$ and hydroxycinnamic acids built on skeleton $\mathrm{C}_{6}-\mathrm{C}_{3}$ (Becker and Szakiel, 2019). Among the hydroxybenzoic acids identified in blue honeysuckle fruits are salycil acid, gentistic acid, protocatechic acid, gallic acid, and vanilic acid. In turn, among hydroxycinnamic acids chlorogenic acid, caffeic acid, m-cumaric acid, and p-cumaric acid were isolated. The main phenolic acid in these fruits is chlorogenic acid, the proportion being significantly determined by the conditions and location of cultivation 
(Jurikova et al., 2012a). In varieties grown in Canada, the content of this acid ranged from 35.0 to $44.0 \mathrm{mg} / 100 \mathrm{~g} \mathrm{FW}$ (Khattab et al., 2015), in Poland 17.24-60.37 $\mathrm{mg} / 100 \mathrm{~g}$ FW (Kucharska et al., 2017), in Slovenia 22.45$46.06 \mathrm{mg} / 100 \mathrm{~g} \mathrm{FW}$ (Senica et al., 2018), and in the Czech Republic 86.62-267.14 mg/100 g FW (Jurikova et al., 2012b). Recent studies have shown that yearly climatic conditions have a significant influence on the content of this acid. Among the cultivars cultivated in Switzerland in the years 2014-2016, a higher content of phenolic compounds, including chlorogenic acid, was noted in 2014 which was characterized by longer sunshine time and lower precipitation sums (Auzanneau et al., 2018). It is worth noting that chlorogenic acid is a compound with prohealth properties. In animal studies, the consumption of chlorogenic acid resulted in pharmacological properties against insulin resistance, obesity, and hepatic steatosis caused by a high-fat diet (Ma et al., 2015). Furthermore, Onakpoya et al. have proven in their clinical trials that chlorogenic acid shows antihypertensive properties (Onakpoya et al., 2015).

The content of flavan-3-ols, present in the form of monomers (catechins) and polymers (procyanidins), was also identified in blue honeysuckle berry. However, procyanidins occur in higher amounts $(228.6-512.0 \mathrm{mg} / 100 \mathrm{~g}$ $\mathrm{DM})$, compared to catechins (22.2-136.1 $\mathrm{mg} / 100$ g DM) (Wojdyło et al., 2013). Procyanidins are compounds with strong antioxidant properties that protect against the development of many diseases caused by excessive oxidative stress in the body. They also affect the taste of raw materials - they can cause astringency or bitterness (Rauf et al., 2019). Flavonoles are the next group of polyphenols present in blue honeysuckle berries. Wojdyło et al. showed that the average content of flavonoles in Polish varieties ranges from 55.7 to $170.0 \mathrm{mg} / 100 \mathrm{~g}$ DM (Wojdyło et al., 2013). Flavonoles are present in blue honeysuckle berries in lower quantities than in fruits such as bilberries, blackcurrants, and blueberries (Jurikova et al., 2012a). The identified flavonoles include quercetin, quercetin derivatives (quercetin-3- $O$-galactoside, quercetin-3-O-glucoside, quercetin-3-Orhamnoside, quercetin-3-O-rutinoside), and luteolin derivatives (luteolin 7-O- $\alpha$-glucoside) (Rupasinghe et al., 2018). According to a recent report, saponin compounds are also present in blue honeysuckle berries. The saponin content, depending on the variety, ranged from 235.78 to $640.79 \mathrm{mg} / 100 \mathrm{~g} \mathrm{FW}$ (Senica et al., 2018).

Iridoids are a very interesting group of compounds that have been recently identified in fruits of blue honeysuckle. They are a large group of secondary metabolites, belonging to the group of cyclopentane monoterpenes. The basic structure of iridoids has a skeleton built of a ring of cyclopentane and pyrane (Oszmiański and Kucharska, 2018). In plants, they can defend against predators and are synthesized in response to the attack of pathogens (Whitehead and Bowers, 2013; Kucharska et al., 2017). Iridoids are compounds often found in medicinal plants-examples include morinda roots (Morinda citrifolia L.) and the bog rosemary (Andromeda polifolia L.). However, they rarely occur in fruits-with the exception of cornelian cherry, cranberry, lingonberry, and bilberry (Heffels et al., 2017; Kuchska et al., 2017). Some types of iridoids may be responsible for the bitterness of plant raw materials; an example could be secoiridoids that are also present in blue honeysuckle berries. Recent studies have shown that the most abundant iridoid in blue honeysuckle berries is loganic acid (Kucharska et al., 2017). However, iridoids such as loganin, sweroside, secologanin, secoxyloganin, pentosides of loganin, and pentosyl-sweroside have also been identified (Kucharska et al., 2017; Oszmiański and Kucharska, 2018; Kucharska and Fecka, 2016). Iridoids are biologically active compounds showing antiinflammatory, neuroprotective, hepatoprotective, hypotensive, and antibiotic properties (Heffels et al., 2017; Oszmiański and 
Kucharska, 2018; Kucharska and Fecka, 2016). Loganin has been shown to be effective in alleviating neurological diseases. In one study, it effectively inhibited the activity of $\beta$-secretase, which is a protease involved in the production of $\beta$-amyloid aggregates - which is one of the causes for Alzheimer's disease (Youn et al., 2013). In addition, loganin also helped alleviate diabetes mellitus by improving liver function and reducing nephropathy (Park et al., 2011; Tundis et al., 2008). On the other hand, secologanin derivatives showed analgesic, antiinflammatory, and anti-allergic properties (Tundis et al., 2008).

\section{The possibilities of application of blue honeysuckle berries in the food industry}

Consumption of both fresh and processed blue honeysuckle berries is particularly popular in Japan and Canada. Until recently, the distribution of fresh blue honeysuckle berries in the European Union was not regulated by law, although there has been increasing interest in the cultivation of this fruit in many countries (Auzanneau et al., 2018). It was not until December 2018 that $L$. caerulea L. was included in the list of traditional foods. Regulation (EU) 2015/2283 of the European Parliament and of the Council permitted blue honeysuckle berries to be legally marketed in the European Union. In comparison, fresh fruit was introduced to the market in Japan as early as in 1950, and in 1970 production was intensified to meet the demands for bakery and confectionery products with these berries (EFSA, 2018).

Fresh fruits intended for consumption are juicy and, depending on the variety, more or less acidic with a bit of bitter taste (Jurikova et al., 2012a). The remaining fruit can be successfully used for processing. Blue honeysuckle berries are used, among others, in the production of jams, jellies, wines, juices, soft drinks, yogurts, candies, puffed snacks, cakes, and ice creams (Celli et al., 2014; EFSA, 2018).

The first very important step affecting the quality of this raw material is harvesting and then postharvest processing. Blue honeysuckle berries are usually ready for harvest at around 6 weeks after pollination, when they have a uniform dark blue color (Dawson, 2017). In smaller farms, manual harvesting is usually used, whereas on larger farms, machine harvesting is used. An unquestionable advantage of blue honeysuckle is the possibility of machine harvesting-especially in countries with high labor costs, i.e. Canada (Celli et al., 2014; Thompson and Barney, 2007). Depending on the intended use, an appropriate way of processing the fruit after harvesting is very important. Fruits which are meant for sale as fresh fruits should be kept at low temperatures as soon as possible and transported to the market because they have a shelf life of only a few days. However, fruits for export or for processing should be frozen immediately. A good way of using fruits is to extract their juice immediately after harvesting. Pasteurized juices can be stored in refrigerated conditions for a longer period of time (Dawson, 2017).

According to a literature review, blue honeysuckle fruits are considered raw materials with a wide spectrum of therapeutic and healthpromoting properties. Therefore, they can be successfully used in the production of functional food and dietary supplements. However, there is relatively less research on the influence of technological processes on the chemical composition of the products from blue honeysuckle berries. It should be noted that in order to obtain products with the highest possible content of bioactive ingredients and consequently the best healthy value, it is necessary to adjust the process parameters during processing in an appropriate and optimal way.

Due to the short harvesting period as well as the short shelf life of the fresh fruit, freezing is a basic technological procedure used in the processing of blue honeysuckle berries. Khattab et al. studied the effect of freezing at -18 and $-32^{\circ} \mathrm{C}$ and blanching as pretreatment conditions before freezing. A reduction in polyphenols 
content and antioxidant activity was observed during the time of storage (especially in the first 3 months). Moreover, storage at $-32^{\circ} \mathrm{C}$ did not significantly increase the content of polyphenolic compounds in the fruits in comparison to the raw materials stored at $-18^{\circ} \mathrm{C}$. Nevertheless, the use of steam blanching before freezing of berries improved the retention of polyphenolic compounds (Khattab et al., 2015). Another study reported that the freezing process had no effect on the content of anthocyanins; however, upon storing frozen products a significant decrease of the anthocyanin content was observed. Additionally, the effect of thawing on the content of anthocyanins in blue honeysuckle berries was investigated. Microwave thawing $(1000 \mathrm{~W}, 17 \mathrm{~min})$ resulted in lower anthocyanin losses compared to room temperature thawing $\left(25 \pm 2^{\circ} \mathrm{C} / 12 \mathrm{~h}\right)$ and refrigerated thawing $\left(4^{\circ} \mathrm{C} / 22 \mathrm{~h}\right)$. Moreover, despite longer thawing time, higher content of anthocyanins was observed in blue honeysuckle berries thawed in refrigerators than those thawed at room temperature (Khattab et al., 2016).

Blue honeysuckle berries after thawing can be utilized primarily for the production of juices. The processing of blue honeysuckle berries into not from concentrate (NFC) juices may be more beneficial, as NFC juices are getting more popular among consumers and have a higher content of nutrients and health-promoting substances than from concentrate (FC) juices (Włodarska et al., 2016). A characteristic of blue honeysuckle berries is their high level of acidity, which is often a feature that is not sensory acceptable to consumers (Wojdyło et al., 2013; Włodarska et al., 2016). For this reason, blue honeysuckle berry juice would be particularly suitable for the production of mixed juices based on juices from fruit containing more sugars, i.e. apples, pears, and peaches. Mixing juices from different fruits is also a way to create an innovative product with functional properties (Grobelna et al., 2019; Lachowicz and Oszmiański, 2018). An important stage in guaranteeing the safety of juices is their preservation process. However, the conventional process of pasteurization at high temperature (above $85^{\circ} \mathrm{C}$ ) degrades valuable nutrients and bioactive compounds from the group of polyphenols, which are often labile and sensitive to technological processes, especially at high temperature. Piasek et al. (2011) compared the preservation of blue honeysuckle berry juices by the conventional method with the method using an EnbioJet microwave pasteurizer. The microwave method of preservation resulted in juices which had no significant degradation of phenolic acids and flavonoids, and lower loss of anthocyanin content that did not exceed $25 \%$.

The next step in the processing of blue honeysuckle berries is the drying process. The drying process can be used to produce powders that can be encapsulated and then marketed as dietary supplements (Celli et al., 2014). However, in the case of blue honeysuckle berries, the drying process of the whole fruit may be complicated because of the thick layer of wax covering the peel which, on the one hand, plays a physiological role in protecting against external factors and pests, but on the other hand it reduces water transport besides slowing the drying process (Oszmiański et al., 2016; Chu et al., 2017). Oszmiański et al. investigated the possibility of using pomace for the production of health-promoting powders from blue honeysuckle berries. It was found that peelbased pomace powders obtained from peelbased pomace contained 4.3 times more bioactive compounds than powders obtained from fresh fruit. In turn, whole fruit-based pomace powders contained twice as much less bioactive compounds than peel-based pomace powders (Oszmiański et al., 2016). Moreover, the utilization of pomace made it possible to streamline the freeze-drying and crushing process because of lower water content in relation to fresh fruit. Interestingly, it has been shown that iridoids evenly accumulate in whole fruits (Oszmiański and Kucharska, 2018), while polyphenols predominate in the skin 
(Oszmiański et al., 2016). Therefore, it was concluded that in order to produce powders richer in iridoids, it is more beneficial to produce them from pomace obtained from whole or crushed berries, rather than only from skins (Oszmiański and Kucharska, 2018). Moreover, the content of iridoid in juices after pressing was also examined. The juices showed a higher content of secologanin and a lower loganin content in comparison to fruits. The technological process of juice production could have caused the breakdown of the bond between C-7 and C-8 of the cyclopentane ring and the formation of a particle of secologanin which is a very bitter substance. As a consequence, the authors concluded that the blue honeysuckle juice might be bitter as compared to berries (Oszmiański and Kucharska, 2018).

It is worth recalling that blue honeysuckle berry is a raw material with proven antibacterial properties (Palíková et al., 2008; Raudsepp et al., 2013; Taira et al., 2015) and would, therefore, find potential use as an antimicrobial agent in food processing. As previously pointed out, blue honeysuckle berries are rich in anthocyanins (Rupasinghe et al., 2018); hence, it would be feasible to obtain a natural red coloring agent from these. This is particularly valuable in the era of growing consumer awareness and the quest for natural food additives.

\section{Conclusions}

The blue honeysuckle berry is a unique horticultural plant, which has been steadily growing in popularity in recent years. Its main advantage is its high content of bioactive compounds and therefore it can be used as a very good component of functional food, dietary supplements, and even medicinal products. However, in the design of high quality functional products based on blue honeysuckle berries it is extremely important to choose appropriate processing methods for this raw material. Future research should especially focus on the influence of different technological processes on the content of bioactive compounds in products from these berries. It is particularly important to maximize the potential of this magnificent plant in the era of more and more common lifestyle diseases.

\section{References}

Auzanneau, N., Weber, P., Kosińska-Cagnazzo, A., Andlauer, W. (2018). Bioactive compounds and antioxidant capacity of Lonicera caerulea berries: Comparison of seven cultivars over three harvesting years. Journal of Food Composition and Analysis, 66, 81-89.

Becker, R., Szakiel, A. (2019). Phytochemical characteristics and potential therapeutic properties of blue honeysuckle Lonicera caerulea L. (Caprifoliaceae). Journal of Herbal Medicine, 16, 100237.

Bell, L., Williams, C. M. (2019). A pilot doseresponse study of the acute effects of haskap berry extract (Lonicera caerulea L.) on cognition, mood, and blood pressure in older adults. European Journal of Nutrition. 58(8), 3325-3334.

Caprioli, G., Iannarelli, R., Innocenti, M., Bellumori, M., Fiorini, D., Sagratini, G., Vittori S., Buccioni M., Santinelli C., Bramucci M., Quassinti L., Lupidi G., Vitali L.A., Petrelli D., Beghelli D., Cavallucci C., Bistoni O., Trivisonno A., Maggi F. (2016). Blue honeysuckle fruit (Lonicera caerulea L.) from eastern Russia: phenolic composition, nutritional value and biological activities of its polar extracts. Food \& Function, 7(4), 1892-1903.

Celli, G. B., Ghanem, A., Brooks, M. S. L. (2014). Haskap Berries (Lonicera caerulea L.)-a Critical Review of Antioxidant Capacity and Health-Related Studies for Potential Value-Added Products. Food and Bioprocess Technology, 6(7), 1541-1554.

Chu, W., Gao, H., Cao, S., Fang, X., Chen, H., Xiao, S. (2017). Composition and morphology of cuticular wax in blueberry 
(Vaccinium spp.) fruits. Food Chemistry, $219,436-442$.

Dawson, J. K. (2017). Concentration and Content of Secondary Metabolites in Fruit and Leaves of Haskap (Lonicera caerulea L.).PhD thesis. Saskatoon, Canada.

EFSA. (2018). Technical Report on the notification of berries of Lonicera caerulea L. as a traditional food from a third country pursuant to Article 14 of Regulation (EU) 2015/2283. EFSA Supporting Publications.

Frier, S. D., Somers, C. M., Sheffield, C. S. (2016). Comparing the performance of native and managed pollinators of Haskap (Lonicera caerulea: Caprifoliaceae), an emerging fruit crop. Agriculture, Ecosystems and Environment, 219, 42-48.

Gawroński, J., Hortyński, J., Kaczmarska, E., Dyduch-Siemińska, M., Marecki, W., Witorozec, A. (2014). Evaluation of phenotypic and genotypic diversity of some Polish and Russian blue honeysuckle (Lonicera caerulea L.) cultivars and clones. Acta Scientiarum Polonorum, Hortorum Cultus, 13(4), 157-169.

Grobelna, A., Kalisz, S., Kieliszek, M. (2019). The effect of the addition of blue honeysuckle berry juice to apple juice on the selected quality characteristics, anthocyanin stability, and antioxidant properties. Biomolecules, 9(11), 744.

Heffels, P., Müller, L., Schieber, A., Weber, F. (2017). Profiling of iridoid glycosides in Vaccinium species by UHPLC-MS. Food Research International, 100, 462-468.

Johnson, M. H., Lucius, A., Meyer, T., Gonzalez de Mejia, E. (2011). Cultivar Evaluation and Effect of Fermentation on Antioxidant Capacity and in Vitro Inhibition of $\alpha$ Amylase and $\alpha$-Glucosidase by Highbush Blueberry (Vaccinium corombosum). Journal of Agricultural and Food Chemistry, 59(16), 8923-8930.

Jurgoński, A., Juśkiewicz, J., Zduńczyk, Z. (2013). An anthocyanin-rich extract from Kamchatka honeysuckle increases enzymatic activity within the gut and ameliorates abnormal lipid and glucose metabolism in rats. Nutrition, 29(6), 898902.

Jurikova, T., Rop, O., Mlcek, J., Sochor, J., Balla, S., Szekeres, L., Hegedusova, A., Hubalek, J., Adam, V., Kizek, R. (2012a). Phenolic profile of edible honeysuckle berries (genus Lonicera) and their biological effects. Molecules, 17(1), 61-79.

Jurikova, T., Sochor, J., Rop, O., Mlček, J., Balla, S.., Szekeres, L., Zitný, R., Zitka, O., Adam, V., Kizek, R. (2012b). Evaluation of polyphenolic profile and nutritional value of non-traditional fruit species in the Czech Republic - A comparative study. Molecules, 17(8), 8968-8981.

Kaczmarska, E., Gawroński, J., DyduchSiemińska, M., Najda, A., Marecki, W., Zebrowska, J. (2015). Genetic diversity and chemical characterization of selected Polish and Russian cultivars and clones of blue honeysuckle (Lonicera caerulea). Turkish Journal of Agriculture and Forestry, 39(3), 394-402.

Khattab, R., Brooks, M. S. L., Ghanem, A. (2015). Phenolic analyses of haskap berries (Lonicera caerulea L.): Spectrophotometry versus high performance liquid chromatography. International Journal of Food Properties, 19(8), 1708-1725.

Khattab, R., Celli, G. B., Ghanem, A., Brooks, M. S.-L. (2015). Effect of frozen storage on polyphenol content and antioxidant activity of haskap berries (Lonicera caerulea L.). Journal of Berry Research, 5(4), 231-242.

Khattab, R., Ghanem, A., Brooks, M. S.-L. (2016). Stability of Haskap Berry (Lonicera Caerulea L.) Anthocyanins at Different Storage and Processing Conditions. Journal of Food Research, 5(6), 67.

Khoo, H. E., Azlan, A., Tang, S. T., Lim, S. M. (2017). Anthocyanidins and anthocyanins: colored pigments as food, pharmaceutical ingredients, and the potential health benefits. Food \& Nutrition Research, 61(1), 1361779. 
Kucharska, A. Z., Fecka, I. (2016). Identification of iridoids in edible honeysuckle berries (Lonicera caerulea $\mathrm{L}$. var. kamtschatica Sevast.) by UPLC-ESIqTOF-MS/MS. Molecules, 21(9), 1157.

Kucharska, Z. A., Sokól-Lętowska, A., Oszmiánski, J., Piórecki, N., Fecka, I. (2017). Iridoids, phenolic compounds and antioxidant activity of edible honeysuckle berries (Lonicera caerulea var. kamtschatica Sevast.). Molecules, 22(3), 120.

Lachowicz, S., Oszmiański, J. (2018). The influence of addition of cranberrybush juice to pear juice on chemical composition and antioxidant properties. Journal of Food Science and Technology, 55(9), 3399-3407.

Ma, Y., Gao, M., Liu, D. (2015). Chlorogenic acid improves high fat diet-induced hepatic steatosis and insulin resistance in mice. Pharmaceutical Research, 32(4), 12001209.

Ochmian, I., Grajkowski, J., Skupien, K. (2008). Field performance, fruit chemical composition and firmness under cold storage and simulated 'shelf-life' conditions of three blue honeysuckle cultigens [Lonicera caerulea]. Journal of Fruit and Ornamental Plant Research, 16, 83-91.

Ochmian, I., Skupień, K., Grajkowski, J., Smolik, M., Ostrowska, K. (2012). Chemical composition and physical characteristics of fruits of two cultivars of blue honeysuckle (Lonicera caerulea L.) in relation to their degree of maturity and harvest date. Notulae Botanicae Horti Agrobotanici Cluj-Napoca, 40(1), 155-162.

Onakpoya, I. J., Spencer, E. A., Thompson, M. J., Heneghan, C. J. (2015). The effect of chlorogenic acid on blood pressure: a systematic review and meta-analysis of randomized clinical trials. Journal of Human Hypertension, 29(2), 77-81.

Oszmiański, J., Kucharska, A. Z. (2018). Effect of pre-treatment of blue honeysuckle berries on bioactive iridoid content. Food Chemistry, 240, 1087-1091.

Oszmiański, J., Wojdyło, A., Lachowicz, S. (2016). Effect of dried powder preparation process on polyphenolic content and antioxidant activity of blue honeysuckle berries (Lonicera caerulea L. var. kamtschatica). LWT - Food Science and Technology, 67, 214-222.

Palíková, I., Heinrich, J., Bednár, P., Marhol, P., Kren, V., Cvak 1, Valentová, K., RŮŽIČKA F , Holá V , Kolár, M., Šimánek, V., Ulrichová, J. (2008). Constituents and Antimicrobial Properties of Blue Honeysuckle: A Novel Source for Phenolic Antioxidants. Journal of Agricultural and Food Chemistry, 56(24), 11883-11889.

Panche, A. N., Diwan, A. D., Chandra, S. R. (2016). Flavonoids: An overview. Journal of Nutritional Science, 5:e47.

Park, C. H., Noh, J. S., Kim, J. H., Tanaka, T., Zhao, Q., Matsumoto, K., Shibahara, N., Yokozawa, T. (2011). Evaluation of morroniside, iridoid glycoside from Corni Fructus, on diabetes-induced alterations such as oxidative stress, inflammation, and apoptosis in the liver of type 2 diabetic $\mathrm{db} / \mathrm{db}$ mice. Biological \& Pharmaceutical Bulletin, 34(10), 1559-1565.

Piasek, A., Kusznierewicz, B., Grzybowska, I., Malinowska-Pańczyk, E., Piekarska, A., Azqueta, A., Collins A. R., Namieśnik, J., Bartoszek, A. (2011). The influence of sterilization with EnbioJet ${ }^{\circledR}$ Microwave Flow Pasteurizer on composition and bioactivity of aronia and blue-berried honeysuckle juices. Journal of Food Composition and Analysis, 24(6), 880-888.

Podsędek, A., Majewska, I., Redzynia, M., Sosnowska, D., Koziołkiewicz, M. (2014). In Vitro Inhibitory Effect on Digestive Enzymes and Antioxidant Potential of Commonly Consumed Fruits. Journal of Agricultural and Food Chemistry, 62(20), 4610-4617. 
Raudsepp, P., Anton, D., Roasto, M., Meremäe, K., Pedastsaar, P., Mäesaar, M., Raald, A., Laikojaae, K., Püssa, T. (2013). The antioxidative and antimicrobial properties of the blue honeysuckle (Lonicera caerulea L.), Siberian rhubarb (Rheum rhaponticum L.) and some other plants, compared to ascorbic acid and sodium nitrite. Food Control, 31(1), 129-135.

Rauf, A., Imran, M., Abu-Izneid, T., IahtishamUl-Haq, Patel, S., Pan, X., Naz, S., Sanches Silva, A., Saeed, F., Rasul Suleria, H. A. (2019). Proanthocyanidins: A comprehensive review. Biomedicine \& Pharmacotherapy, 116, 108999.

Rupasinghe, H. P. V., Arumuggam, N., Amararathna, M., De Silva, A. B. K. H. (2018). The potential health benefits of haskap (Lonicera caerulea L.): Role of cyanidin-3-O-glucoside. Journal of Functional Foods, 44, 24-39.

Rupasinghe, H. P.V., Boehm, M. M. A., Sekhon-Loodu, S., Parmar, I., Bors, B., Jamieson, A. R. (2015). Anti-inflammatory activity of haskap cultivars is polyphenolsdependent. Biomolecules, 5(2), 1079-1098.

Rupasinghe, H. P. V., Yu, L. J., Bhullar, K. S., Bors, B. (2012). Short Communication: Haskap (Lonicera caerulea): A new berry crop with high antioxidant capacity. Canadian Journal of Plant Science, 92(7), 1311-1317.

Senica, M., Stampar, F., Mikulic-Petkovsek, M. (2018). Blue honeysuckle (Lonicera cearulea L. subs. edulis) berry; A rich source of some nutrients and their differences among four different cultivars. Scientia Horticulturae, 238, 215-221.

Taira, T., Yamaguchi, S., Takahashi, A., Okazaki, Y., Yamaguchi, A., Sakaguchi, H., Chiji, H. (2015). Dietary polyphenols increase fecal mucin and immunoglobulin A and ameliorate the disturbance in gut microbiota caused by a high fat diet. Journal of Clinical Biochemistry and Nutrition, 57(3), 212-216.
Takahashi, A., Okazaki, Y., Nakamoto, A., Watanabe, S., Sakaguchi, H., Tagashira, Y., Kagii, A., Nakagawara, S., Higuchi, O., Suzuki, T., Chiji, H. (2014). Dietary anthocyanin-rich Haskap phytochemicals inhibit postprandial hyperlipidemia and hyperglycemia in rats. Journal of Oleo Science, 63(3), 201-209.

Thompson, M. M., Barney, D. L. (2007). Evaluation and Breeding of Haskap in North America. Journal of the American Pomological Society, 61(1), 25-33.

Tundis, R., Loizzo, M., Menichini, F., Statti, G., Menichini, F. (2008). Biological and Pharmacological Activities of Iridoids: Recent Developments. Mini-Reviews in Medicinal Chemistry, 8(4), 399-420.

Wang, Y., Zhu, J., Meng, X., Liu, S., Mu, J., Ning, C. (2015). Comparison of polyphenol, anthocyanin and antioxidant capacity in four varieties of Lonicera caerulea berry extracts. Food Chemistry, 197, 522-529.

Whitehead, S. R., Bowers, M. D. (2013). Iridoid and secoiridoid glycosides in a hybrid complex of bush honeysuckles (Lonicera spp., Caprifolicaceae): Implications for evolutionary ecology and invasion biology. Phytochemistry, 86, 57-63.

Włodarska, K., Pawlak-Lemańska, K., Górecki, T., Sikorska, E. (2016). Perception of Apple Juice: A Comparison of Physicochemical Measurements, Descriptive Analysis and Consumer Responses. Journal of Food Quality, 39(4), 351-361.

Wojdyło, A., Jáuregui, P. N. N., CarbonellBarrachina, Á. A., Oszmiański, J., Golis, T. (2013). Variability of phytochemical properties and content of bioactive compounds in Lonicera caerulea L. var. kamtschatica berries. Journal of Agricultural and Food Chemistry, 61(49), 12072-12084.

Youn, K., Jeong, W.-S., Jun, M. (2013). $\beta$ Secretase (BACE1) inhibitory property of loganin isolated from Corni fructus. Natural Product Research, 27(16), 1471-1474. 